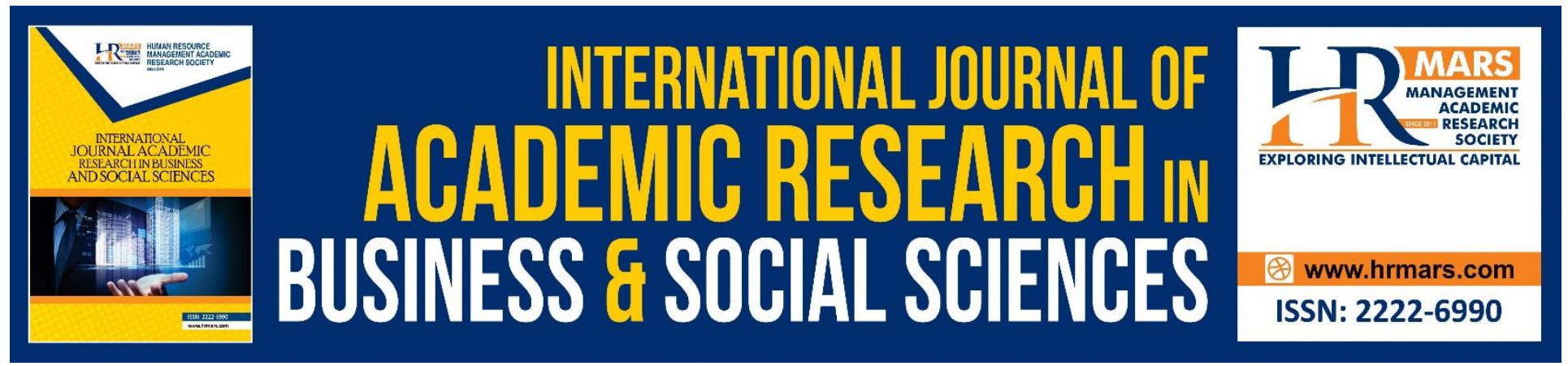

\title{
Images in the Human Mind: Between Stereotype and Reality of the Ethnic Groups in Malaysia
}

Rohaizahtulamni Radzlan, Mohd Roslan Rosnon \& Jamilah Shaari

To Link this Article: http://dx.doi.org/10.6007/IJARBSS/v10-i16/9020～DOI:10.6007/IJARBSS/v10-i16/9020

Received: 24 October 2020, Revised: 18 November 2020, Accepted: 30 November 2020

Published Online: 17 December 2020

In-Text Citation: (Radzlan et al., 2020)

To Cite this Article: Radzlan, R., Rosnon, M. R., \& Shaari, J. (2020). Images in the Human Mind: Between Stereotype and Reality of the Ethnic Groups in Malaysia. International Journal of Academic Research in Business and Social Sciences, 10(16), 412-422.

Copyright: (C) 2020 The Author(s)

Published by Human Resource Management Academic Research Society (www.hrmars.com)

This article is published under the Creative Commons Attribution (CC BY 4.0) license. Anyone may reproduce, distribute, translate and create derivative works of this article (for both commercial and non-commercial purposes), subject to full attribution to the original publication and authors. The full terms of this license may be seen

at: http://creativecommons.org/licences/by/4.0/legalcode

Special Issue: Youth and Community Wellbeing: Issues, Challenges and Opportunities for Empowerment V2, $2020, \mathrm{Pg} .412$ - 422

Full Terms \& Conditions of access and use can be found at http://hrmars.com/index.php/pages/detail/publication-ethics 


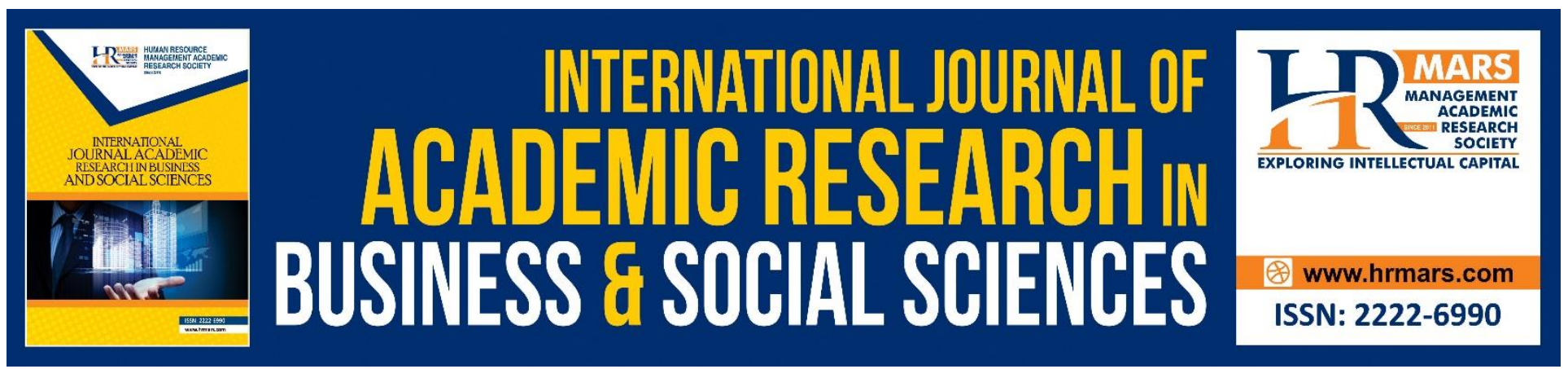

\title{
Images in the Human Mind: Between Stereotype and Reality of the Ethnic Groups in Malaysia
}

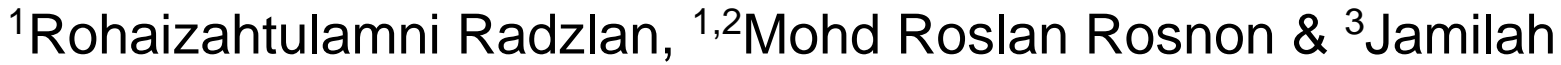 Shaari}

${ }^{1}$ Institute for Social Science Studies, Universiti Putra Malaysia, Malaysia, ${ }^{3}$ Department of Social \& Development Sciences, Faculty of Human Ecology, Universiti Putra Malaysia, Malaysia, ${ }^{3}$ School of Health Sciences, Universiti Sains Malaysia, Malaysia

Email: roslan_rosnon@upm.edu.my

\begin{abstract}
Malaysia is a country of diverse ethnicities and cultures. This phenomenon has created various social perceptions and stereotypes between different ethnic groups. Stereotypes serve as a cognitive process for organizing social information in a complex social environment by facilitating information processing. Limited human cognitive ability influences the simple categorization process to operate and receive information. In fact, when one confirms stereotypes against a group it will lead to bias in thought as well as behaviour. Therefore, this paper scrutinizes in general about the belief on the ethnic social cultural that has been embedded in human mind. This research also reviews the stereotypical as a representation of the cognitive and reality of this complex social environment.

Keywords: Stereotypes, Attitudes, Perception, Ethnic, Ethnic Relation.
\end{abstract}

\section{Introduction}

Humans live by having constant interaction with one other and indirectly formed a social group, an organization or a socio-cultural society. Accordingly, this study focuses on social cognition, a 'subtopic' to social psychology by focusing on someone who processes, stores, and uses information about others in social problems (Fiske \& Taylor, 2008). Thus, the study of social psychology is a scientific study of the content of a person's thoughts, feelings, and behaviour that can be measured in humans (Rogers, 2011). This study explores the processing of information and knowledge of a community group to other community groups found in Malaysia.

The diverse ethnicities and cultures in Malaysia resulted from the British colonialism. The British introduced a policy that separated the major ethnic groups in Malaysia, namely the Malays, Chinese and Indians, which then resulted to racial polarization. Incident such as riot on May 13, 1969 is part of the black history of inter-racial relations in Malaysia (Zainal \& Saleh, 2012). Rabushka (1971) found that there was no detailed and thorough study that measured and evaluated the attitude of the multiracial community regarding the incident. 
INTERNATIONAL JOURNAL OF ACADEMIC RESEARCH IN BUSINESS AND SOCIAL SCIENCES

Vol. 10, No. 16, Youth and Community Wellbeing: Issues, Challenges and Opportunities for Empowerment V2. 2020, E-ISSN: 2222-6990 @) 2020 HRMARS

Rabushka then conducted a survey study of racial stereotypes based on socio-cultural characteristics in Malaysia through interviews. The study explained that the Chinese was more ethnocentric and tolerance compared to the Malays. Several researchers believed that due to the diverse multicultural environment, inter-ethnic relations issues that revolve around race, politics, economy, social class and social inequality are inevitable (Shamsul, 2011; Amar, Hazri, Najeemah, 2013; Noor \& Mansor, 2017). Inter-ethnic relations in Malaysian society are further characterized as 'stable tensions' (Shamsul, 2011) and 'worrying and fragile state' (Kim, 2007). It can be argued that socio-cultural diversity would be one of the challenges in promoting social integration among people of different ethnic groups. Thus, study of ethnic stereotypes is essential to be explored as the phenomena that occur in socio-cultural diversity could be understood and explained through the image in human mind approach.

\section{Stereotypes}

The origin of the term or terminology and etymology for stereotypes is originated from the French

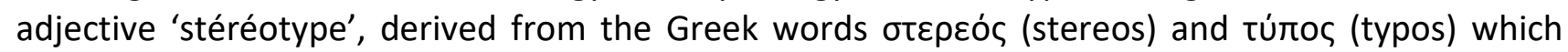
means rigid and trace respectively. The term was introduced by Firmin Didot in 1798 during the era of the publishing industry in France, to refer the metal plate's printer which produce images (Leyens, Yzerbyt, \& Schadron, 1994; Jones \& Colman, 1996). Meanwhile, in 1922 the term stereotype was first introduced in the social science field by Walter Lippmann. According to Walter Lippmann, stereotypes are 'images in the human mind' (Leyens, Yzerbyt, \& Schadron, 1994; Dovidio, Hewstone, Glick \& Esses 2010). He stated that the images in the mind helped people to understand the environment based on direct knowledge of society and events. Therefore, this concept can be summarized as a view of the social environment based on an image or label through general knowledge that has been embedded in one's mind.

Various concepts and definitions of stereotypes have been introduced in line with the research field approach. In the field of sociology, this approach was introduced by Adorno, Frenkel-Brunswik. For instance, the sociology field's approach that was initially introduced by Adorno, Frenkel-Brunswik, Levinson and Sanford (1950), specified stereotype as the foundation in generalizing a certain group's with negative attributes which reflected prejudice. Meanwhile, stereotype concept was also introduced in the economy's field approach by Arrow (1973), as a manifestation of statistical discrimination due to the existence of imbalance's views within the group. Schneider, Hastorf and Ellsworth (1979), in turn, began to introduce the concept of stereotypes to explain the differences between groups through simple information processing based on cognitive schemes. The concept of stereotyping as a cognitive scheme is a social cognition approach that is seen as fundamental in the field of social psychology. In fact, nowadays, social psychology researchers define stereotypes as cognitive structures that contain knowledge, beliefs and expectations about social groups (Pauker, Ambady \& Apfelbaum, 2010). Based on the various definition of stereotypes, it can be concluded that stereotype is to generalize a group and its differences.

The use of stereotypes is usually to explain beliefs about a person or a group. Ajtony (2011), explained that stereotypes emerged as a way to facilitate when perceptions occur by processing information based on stored knowledge. In fact, stereotypes were often used to generalize about a person based on a particular category, whether in the form of the similar characteristics or behaviours of the members of his group (Katz \& Braly, 1933; Fiske \& Taylor, 2008; Stangor, 2009; Rohaizahtulamni et 
INTERNATIONAL JOURNAL OF ACADEMIC RESEARCH IN BUSINESS AND SOCIAL SCIENCES

Vol. 10, No. 16, Youth and Community Wellbeing: Issues, Challenges and Opportunities for Empowerment V2. 2020, E-ISSN: 2222-6990 @) 2020 HRMARS

al., 2018). In addition, stereotypical views also contained a combination of positive and negative traits (Operario \& Fiske, 2003; Ruble \& Yan, 2013) depending on the frequency of information received (Schneider, 2004; Tan et al., 2010). Hence, the study of stereotypes explores what goes into one's mind when social concepts are activated. Stereotypes also served as knowledge and justification of a person or social group (Crandall, Bahns, Warner \& Schaller, 2011) based on their categorization and activation which associated with illusion correlation effects (Hamilton \& Gifford, 1976; Pelley, Reimers, Spears, Beesley \& Murphy, 2010). Thus, categorization in stereotypes is a normal process for humans to allow one to quickly understand the world around them.

\section{History of Ethnic Group in Malaysian}

The history of Malaysia derived from the Malay Policy system and started with the word 'Malaya'. In addition, from the 6 th century to the $10^{\text {th }}$ century, the word "Malay" was a reference to the name of a place and was not specifically referring to any national group. However, at the beginning of the 11th century, the word 'Malay' was used in naming the national group. Thus, according to Ridhuan (2010), the Malaya, Malaysian and Malay terms referred to the states of Malay or Malaya or Land of the Malays. He further explained that Malaysian or Malaya belonged to a nation called Malay. In fact, in the 15th century during the Malacca Sultanate golden era, the Malacca sultanate was known worldwide as the Malay ruled government (Abidin, 1997). However, society and politics in Malaya began to change during the colonialization.

In 1931, the number of non-Malays census had exceeded the number of Malays in Malaya. This was the result of migration, brought by the British colony for the purposes of farming and mining (Comber, 2007). This is further supported by Shamsul (2011) that pluralism in Malaysia was the result from the British colonialization era. The British introduced the policy of intervention of the socio-political structure of traditional Malay society and brought people from China and India which resulted to racial diversity. This situation has resulted to the use of 'Malay supremacy' for the first time in the history of the Malayan and caused a sense of danger. In fact, the effects of the 'split and order' policy introduced by the British colony created social and cultural isolation even under the same rule. Haniffa (2017), explained that the policy of 'division and order' caused racial marginalization based on the economic prosperity zone. Therefore, the phenomenon created various views and identification of race that based on the races' economic function.

The socio-economic imbalances led to misunderstandings and conflicts among the citizens. For example, 'Black history' of racial riot on 13 May 1969, Kampung Rawa tragedy 1998 and Kampung Medan tragedy 2001 (Hairol et al., 2020). It was evident that negative and threatened feelings that influenced by the economic and political games could cause social conflicts. For examples, race-based political parties were established post-independence (Husin, 2015) as well as economic imbalances according to ethnicity in 1970 (Mamat, Saat \& Ariffin, 2014) had caused political competition and unhealthy resources. The situation had indirectly affected the existence of segmentation in politics (Ramli et al., 2018) and the gap of social unity became difficult to bridge. In addition, there were ultrapluralist groups who wanted to create provocation on religion and racism that would affect interracial harmony (Ramli et. al, 2018). This situation adds to the difficulty of cultivating and enhancing unity among different ethnic groups. 
INTERNATIONAL JOURNAL OF ACADEMIC RESEARCH IN BUSINESS AND SOCIAL SCIENCES

Vol. 10, No. 16, Youth and Community Wellbeing: Issues, Challenges and Opportunities for Empowerment V2. 2020, E-ISSN: 2222-6990 @) 2020 HRMARS

Currently, the total population of Malaysia is around 28.5 million which comprises of $67.3 \%$ Malays, 24.5\% Chinese, $7.3 \%$ Indians and $0.9 \%$ others (Malaysian Department of Statistics, 2014). There are three main ethnics in Malaysia which are Malays, Chinese and Indians. In addition, there are also indigenous groups of Sabah and Sarawak such as the Kadazans, Ibans, Dusuns, and many more. This has made Malaysia rich with various cultural heritages due to the different religious and traditions profess by different ethnics. However, this diversity sometimes triggers conflicts and threatens national security. Thus, Malaysians today has been challenged to strengthen the ties and relations while dismantled the wall of segregation between different ethnic groups (Chang, Azizan \& Amran, 2014). Therefore, during post-independence, among the government's initial efforts in achieving national unity and integration were to introduce Rukun Negara (Sani, 2009) and the New Economic Policy (NEP) (Mamat, Saat \& Ariffin, 2014). In fact, until now various approaches have been taken to maintain and enhance inter-ethnic unity in Malaysia.

\section{Between Stereotype and Reality}

Cognitively, stereotypes are general beliefs about other groups based on simplified information (Stangor \& Schaller, 1996; Tan et al., 2010). For example, Malays are often portrayed as lazy (Faisal and colleagues, 2010), Chinese as greedy (Shamsul, 2011: Chua et al., 2013) and Indian as drunkards (Ramli et. al., 2018). However, is it true that all these images represent the nature of all its members? Forbes (2019), listed more than five Malays as the richest people in Malaysia among which Tan Sri Syed Mokhtar Al-Bukhary, Tan Sri Syed Azman Syed Ibrahim and several others. Meanwhile, there are also Chinese individuals who are famous for being generous at making donations like Kuan Chee Heng or known as Mr. Potato who is viral on social media (Fong, 2018) and Datuk Lee Chong Wei who went viral for donating for a mosque (Mat, 2020). In addition, based on the statistics of patients admitted to the Hospital Kuala Lumpur (HKL) it was found that a high number of Chinese individuals were admitted for alcohol related accidents compared to other ethnicities like Indians and Malays (Saleh \& Salleh, 2011). This explains that the abovementioned views regarding the three major ethnics are not necessarily true. Therefore, what are the actual reasons that cause these stereotypical perceptions or views of the different ethnics in Malaysia?

There are few stereotype views on Malaysians ethnics based on historical perspective by European's writers. For instance, Swettenham (1967), explained that Malays were categorized as a slacker without any reason. Plus, Hirschman (1986) described Malays as a group of lazy, less oriented and frequently portrayed dissatisfaction for heavy work. He also explained that the Chinese was often categorized as achievement-oriented, hardworking, opportunity-taking, greedy and great businessmen. Meanwhile, Indians in the plantations were considered low in mental capacity, less self-oriented and poor achievement compared to Indians who live in the city. Those Indians in the city were seen to replicate Chinese characteristics, especially in terms of trade and economy but they were not considered as oriented workers like the Chinese. In fact, Hirschman (1986) explained that the views of Malay's ethnic as 'lazy' was due to their lack of interest in working at rubber plantations and tin mines compared to others ethnics i.e. Chinese and Indian who were diligent and hardworking.

According to Hirschman (1986), the refusal of Malay's ethnic to work at farms and mines was influenced by environmental and social factors as they found that there were a lot of natural resources available such as fish and rice which did not require them to work hard in the fields or mines. Similarly, Mahathir (2010) explained that the agricultural sector of the economy was to match 
INTERNATIONAL JOURNAL OF ACADEMIC RESEARCH IN BUSINESS AND SOCIAL SCIENCES

Vol. 10, No. 16, Youth and Community Wellbeing: Issues, Challenges and Opportunities for Empowerment V2. 2020, E-ISSN: 2222-6990 @) 2020 HRMARS

the attitude of the Malays who were comfortable with the existing situation and did not have to compete with other races. Abdul Aziz (2005) further explained that the Malays adhered to the teaching of Islam; to be satisfied with what they have. However, Syed Sheikh Al-Hadi explained that such understanding indicated lack of in-depth understanding of Islam. Abdul Aziz (2004) supported the statement and further commented that it was also due to the absence of ijtihad and taqlid in the everyday lives of Malay Muslims. Due to the lack of in-depth knowledge on Islam in which, Malays believed that they should always feel sufficient with what they have, has led to the misconceptions of the Malays attitudes as being lazy.

Another reason for the association of Malays and lazy was the broad use of the word lazy to also indicate other physical conditions like 'unhealthy', 'tired' or 'busy' (Asrul, 2002). The Malay language is often described as subtle and indirect (Goddard, 1997). Thus, the word lazy in the Malay community could mean the literal meaning of lazy, or tired, busy or unhealthy depending on the context of the communication. Similarly this particular quality of Malays was evident centuries ago as mentioned by (Swift, 1965) that Malay culture often was conscious of saving face and others' thoughts and opinions of themselves.

Chinese ethnic is often categorized or stereotyped as a 'greedy' ethnic (Shamsul, 2011: Chua et al., 2013). Yeoh \& Yeoh (2015), also stated that the Chinese was characterised as a person who tends to take risks and competitive behavioural characteristics. He explained that Chinese believed that they were the minority and they had to work hard and compete with other cultures in order to succeed in life. The Chinese also believed that the purpose of life and fate could be changed if proper exchanges were offered to the gods (Lim, 2001). In fact, the Chinese also believed that success can only be achieved through hard work, diligence and perseverance (Asma, 1996). Besides, the nature of Chinese's ethnic seriousness, especially in the pursuit of knowledge, was also contributed by the structure of Confucius' influence that placed educated people in the highest social hierarchy (Wan Husin, 2012). Therefore, the Chinese was willing to sacrifice and worked hard to get a perfect education and success. With this nature, they are seen as greedy but also more energetic and are committed to self-improvement.

Ethos factor of Chinese's ethnic immigrants from different regions as well as having known the meaning of hardship and poverty, prompted them to work harder so that future generations will not experience the same thing (Abdul Aziz, 2005). In fact, according to the view of modernization theory, the Chinese were more appreciative of the value of modern life than other ethnics which were still traditional (Husin, 2012). This value of modernity is a cultural attitude related to the way we act and interact with modern institutions and ultimately form an industrial society. Due to the circumstances, values and beliefs held by the Chinese, make them visible or stereotypical as 'greedy' and have competitive behaviour compared to other ethnic groups such as Malays and Indians.

On the other hand, the Indians are often seen or stereotyped as 'aggressive', 'unreliable' and 'drunkard' types of ethnic group (Hirscham, 1986; Belle, 2015). The behaviour of the Indians who often portrayed as behaving badly and alcoholic might be due to the frustration of the shortcomings and difficulties that they must face in order to survive in Malaysia especially those who worked at the plantations (Abdul Aziz, 2005). They were pressured by the employers ever since the first generation of the ethnic and they were mostly trapped in poverty, illiterate and incapable. Apart from that, Abdul 
INTERNATIONAL JOURNAL OF ACADEMIC RESEARCH IN BUSINESS AND SOCIAL SCIENCES

Vol. 10, No. 16, Youth and Community Wellbeing: Issues, Challenges and Opportunities for Empowerment V2. 2020, E-ISSN: 2222-6990 @) 2020 HRMARS

Aziz (2005) also explained the belief in the doctrine of karma and dharma in Hindus causing the Indians to believe that the hardships or misfortunes that they experienced were due to the retribution they had to bear.

This situation caused the Indians to be less motivated and low self-esteem. This has led to fatalistic attitude as well as committing bad behaviour and drinking alcohol as a result of frustration. The frustration effects of Indian's culture and their environment had influence other ethnic's views on their behaviour which then they are stereotyped as 'aggressive', 'unreliable' and 'drunken'.

The study by Mansor and Nazri (2014), explained that racial stereotypes in Malaysia was more reflective of individual interests, self-esteem and social status rather views on the behaviour of ethnic groups such as previous studies. The identity of Malaysian society was always seen in the form of polarization. Such as Malay's ethnic dominated politics and the public sector (Noraini, 2007; Azhar, Rosman, Fauzi and Koharuddin, 2013; Janssens, Verkuyten \& Aqeel, 2015), Chinese dominated the economic sector (Shamsul Haque, 2003; Noraini, 2007; Mohd Azhar, Rosman, Muhammed Fauzi \& Koharuddin, 2013; Janssens, Verkuyten \& Aqeel, 2015), and Indians was considered as marginalized minorities (Cangià, 2014; Janssens, Verkuyten \& Aqeel, 2015). Thus, the stereotypical view of race in Malaysia was often described based on social status because, $53.9 \%$ of Chinese work in high-income fields such as accounting, law and engineering, compared to only $28.9 \%$ for Malay and $15.5 \%$ for Indians. Meanwhile, the average income of Chinese was RM2 896, compared to RM1 600 for Malays (Janssens, Verkuyten, \& Khan, 2015). In fact, Bumiputera viewed the Chinese as more dominant in the economy but did not play a role in helping other races (Asrizal, 2013; Mamat, Saat, \& Ariffin, 2014). Therefore, views on differences in social status also reflect the power between groups and encourage the formation of stereotypes that are affected by the bias and in-group favouritism. Besides, feelings of being threatened by in-group's position to maintain its culture and social status causes negative stereotypes to occur.

Social psychologist expert believes that a person's stereotypes are activated when they feel threatened to the social system and at the time and are motivated to defend it (Puddifoot, 2017). For instance, the stereotypes of Black people during the era of slavery in the United States was described as very happy, such as children and lovers, but during the struggle to abolish slavery, these stereotypes turned Black people into a threat (UhImann et al. 2011; Alexander, 2011). This also explains the nature of stereotypes to be negative when there are constraints or social challenges involved. Matusitz (2012) explained that lack of information, less education or limited exposure to culture as well as other ethnic lifestyles would result to stereotypical effects. Indirectly humans make inferences about the nature of a person excessively based on the characteristics of the group he belongs to. In addition, there is also views of past researchers that, confusion in stereotypes with real reality is due to the effect of bias on the group itself and better than the out-group. The Social Identity Theory by Tajfel (1982) was often used in stereotypical studies explaining that humans naturally tended to find similar traits in groups as well as creating ' $u s^{\prime}$ and 'they' categories. This dimension related to social identity for high group status. According to Betterncourt, Gwinner and Meuter (2001), in their study showed that individuals perceived and evaluated something about in the group more positively than the out-group. Therefore, the stereotypical approach can indirectly reflect the reality of the relationship between groups. 
INTERNATIONAL JOURNAL OF ACADEMIC RESEARCH IN BUSINESS AND SOCIAL SCIENCES

Vol. 10, No. 16, Youth and Community Wellbeing: Issues, Challenges and Opportunities for Empowerment V2. 2020, E-ISSN: 2222-6990 @) 2020 HRMARS

\section{Conclusion}

This study focuses on reviewing stereotypical as a representation of the cognitive and reality in complex social environment. Thus, stereotype is a key construct for measuring the level of social cohesion among citizen in Malaysia. Besides, exploring stereotypical views is one of the aspects to scrutinize 'social health condition' among society, especially in Malaysia which has diverse sociocultural. Stereotype could be used as a quick explanation either positive or negative labels when there are threats such as social constraints or challenges. This is because, we tend to identify people of certain quality belong to the in-group and some in the out-group. One of the reasons for such behaviour is the insecurities among humans and because of that, we need specific in-group members to provide the sense of assurance.

It can be concluded that stereotypes among ethnics exist because of our behaviour of labelling people who are different than us; culturally, ethnically, behaviourally and so on. Many scholars agreed that stereotype and prejudice are results of past ethnics' tragedies and history. However, it is a wonder to how the negative perceptions of ethnics are ongoing until today despite that the causes of the past tragedies had been resolved? At present, stereotype and prejudice might not be able to be fully abolished. However, if the community behave positively towards people of different ethnics, stereotypes and prejudice can be overcome and negative effects on ethnics can be reduced as well.

\section{Corresponding Author}

Dr. Mohd Roslan Rosnon

Institute for Social Science Studies, Universiti Putra Malaysia, 43400 UPM Serdang

Email: roslan_rosnon@upm.edu.my

\section{References}

Abdul Aziz, A. R. (2004). Pembangunan etos budaya etnik Melayu mengharungi pemodenan. In: Seminar Antarabangsa Nilai dalam Komuniti Pasca Modenisme (SIVIC 2004), 4-6 September 2004, Hotel City Bayview Langkawi.

Abdul Aziz, B. (2005). Islam Dalam Perlembagaan Malaysia. Kuala Lumpur: Intel Multimedia Publication.

Adorno, T. W., Frenkel-Brunswik, E., Levinson, D. J., \& Sanford, R. N. (1950). The authoritarian personality. Harpers.

Sani, A. Z. S. (2009). Rukun Negara Dicipta Perpaduan Digapai. Membina Bangsa Malaysia: Integrasi Nasional. Vol.4:469-480.

Ajtony, Z. (2011). Ethnic Stereotype- Impediments or Enhancers of Social Cognition? Acta Universitatis Sapientiae. Philogica, 3 (2), 134-155.

Alexander, M. (2011). "The New Jim Crow." Ohio State Journal of Criminal Law 9 (1): 9-27.

Arrow, K. J. (1973) 'The Theory of Discrimination', in O. Aschenfelter and A. Rees (eds) Discrimination in Labor Markets (Princeton: Princeton University Press).

Asma, A. (1996). Going Global - Cultural Dimensions in Malaysian Management. Kuala Lumpur: Malaysian Institute of Management.

Asrizal, M. R. (2013). Jurnal Biro Tatanegara: sejarah pembentukan negara bangsa dan 1Malaysia. Bil. 1. Putrajaya: Biro Tatanegara.

Asrul, Z. (2002). The Malay Ideals. Kuala Lumpur: Golden Books Centre Sdn. Bhd. 
INTERNATIONAL JOURNAL OF ACADEMIC RESEARCH IN BUSINESS AND SOCIAL SCIENCES

Vol. 10, No. 16, Youth and Community Wellbeing: Issues, Challenges and Opportunities for Empowerment V2. 2020, E-ISSN: 2222-6990 @) 2020 HRMARS

Belle, C. V. (2015). Tragic orphans: Indians in Malaysia. Singapore: Institute of Southeast Asian Studies.

Bettencourt, L. A., Gwinner, K. P., \& Meuter, M. L. (2001). A Comparison of Attitude, Personality, and Knowledge Predictors of Service-Oriented Organizational Citizenship Behaviors. Journal of Applied Psychology, 86(1), 29-41.

Cangià, F. (2014). The Hindu Rights Action Force and the Definition of the 'Indian Community' in Malaysia. Sociological Research Online, 19(4), 82-95.

Chang, L. W., Azizan, B., \& Amran, M. (2014). National Unity at the University Level: Importance of Civilisational Dialogue and Way Forward. European Scientific Journal, 4, 173-186.

Chua, B. S., Jasmine, A. M., Lailawati, M., Chan, H. Z., Asong, J., Ho, C. J., Suwaibah, Z., Rosnah, I., \& Shamsul, A. B. (2013). The Perception of Characteristics, Behaviors, Cultures and Traditions toward Own and Other Ethnic Groups. International Journal of Asian History, Culture and Tradition, 1 (1), 1 - 10.

Comber, L. (2007). Peristiwa 13 Mei: Sejarah Perhubungan Melayu - Cina. Petaling Jaya: IBS Buku Sdn. Bhd.

Crandall, C. S., Bahns, A. J., Warner, R., \& Schaller, M. (2011). Stereotypes as Justifications of Prejudice. Personality and Social Psychology Bulletin, 37 (11), $1488-1498$.

Dovidio, J. F., Hewstone, M., Glick, P., \& Esses, V. M. (2010). Prejudice, Stereotyping and Discrimination: Theoretical and Empirical Overview. The SAGE Handbook of Prejudice, Stereotyping and Discrimination, 2 - 28.

Faisal, I., Norhayati, A. M., Thong, L. K., Ezhar, T., Khairul, H., \& Zalina, D. (2010). Re-Visiting Malay Stereotypes: A Case Study among Malaysian And Indonesian Chinese Students. ResearchGate, 3 (2), $153-163$.

Fiske, S. T., \& Taylor, S. E. (2008). Social Cognition: From Brains to Culture. New York, NY: McGrawHill.

Forbes. (2019). Malaysia's 50 Richest List.

Goddard, C. (1997). Cultural values and "cultural scripts" of Malay (Bahasa Melayu). Journal of Pragmatics, 27, 183-201.

Hairol, A., Azlili, N. H., Azlina, A., Mahadee, M. I., \& Marzudi, M. Y. (2020), Hubungan Sosial Rentas Etnik ke Arah Pengukuhan Kesepaduan Sosial di Malaysia. Islamiyyat. 42, 107-113.

Hamilton, D. L., \& Gifford, R. K. (1976). Illusory Correlation in Interpersonal Perception: A Cognitive Basis of Stereotypic Judgments. Journal of Experimental Social Psychology, 12 (4), $392-407$.

Haniffa, M. A. (2017). Konflik Kaum Selepas Pendudukan Jepun di Tanah Melayu: Kajian Awal Berasaskan Sumber Lisan. Jurnal Peradaban, 10, 16-37.

Hirschman, C. (1986). The Making of Race in Colonial Malaya: Political Economy and Racial Ideology. Sociological Forum, 1 (2), 330 - 61.

Janssens, H., Verkuyten, M., \& Aqeel, K. (2015). Perceived social structural relations and group stereotypes: A test of the Stereotype Content Model in Malaysia. Asian Journal of Social Psychology. 18, 52-61.

Jasmine, A. M., Chua, B. S., Lailawati, M., Aminuddin, I. L., Shamsul, A. B., \& Joseph, A. (2014). A Multiethnic Perception through the Eyes of Students. International Journal of Information and Education Technology, 4 (3), $249-253$.

Jones, E., \& Colman, A. (1996). Stereotypes. In the Social Science Encyclopedia (2nd Ed, pp. 843-844). London: Routledge. 
INTERNATIONAL JOURNAL OF ACADEMIC RESEARCH IN BUSINESS AND SOCIAL SCIENCES

Vol. 10, No. 16, Youth and Community Wellbeing: Issues, Challenges and Opportunities for Empowerment V2. 2020, E-ISSN: 2222-6990 @) 2020 HRMARS

Katz, D., \& Braly, K. (1933). Racial stereotypes of one hundred college students. The Journal of Abnormal and Social Psychology, 28(3), 280-290.

Khalim, Z., \& Norshidah, M. S. (2012). A Case Study of Ethnic Behavior among Students in Urban and Rural Schools. The International Journal of Knowledge, Cultue, \& Change Management, 11 (3), $161-169$.

Le Pelley, M. E., Reimers, S. J., Calvini, G., Spears, R., Beesley, T., \& Murphy, R. A. (2010). Stereotype formation: Biased by association. Journal of Experimental Psychology: General, 139(1), 138161.

Leyens, J. P., Yzerbyt, V., \& Schadron, G. (1994). Stereotypes and Social Cognition. SAGE Publication.

Lim, L. (2001). Work-related values of Malays and Chinese Malaysians. International Journal of Cross Cultural Management, 1, 229-246.

Mahathir, M. (2010). The Malay Dilemma: With a New Preference. Marshall Cavendish International Asia Pte Ltd.

Malaysia Department of Statistics. (2014). Retrieved on May 31, 2014 from http://www.statistics.gov.my/portal/images/stories/files/LatestReleases/vital/Vital_Statistics _Malaysia_2012.pdf

Mamat, M. A. A., Saat, I., \& Ariffin, K. (2014). Impak Dasar Ekonomi Baru ke atas Peningkatan Ekonomi Bumiputera Selepas Tragedi 13 Mei 1969. Jurnal Perspektif. 6 (3), 138-151.

Mansor, M. N. (2010). Hubungan Melayu dan Cina di Malaysia masa kini: buta dengan perubahan realiti sosial Negara. Demokrasi (Jurnal ilmiah Politik Kenegaraan) 9(2): 186-20.

Mansor, M. N., \& Nazri, M. (2014). Ethnic Tolerance among Students of Public Higher Learning Institutions in Malaysia. World Applied Sciences Journal, 29(3), 388-401.

Mat, A. A. (2020). Terkejut Tular, Chong Wei Mengaku tak Suka Menunjuk. Harian Metro. https://www.hmetro.com.my/arena/2020/05/584037/terkejut-tular-chong-wei-mengakutak-suka-menunjuk

Matusitz, J. (2012). Relationship between Knowledge, Stereotyping, and Prejudice in Interethnic Communication. Revista de Turismo y Patrimonio Cultural. 10 (1), 89-98.

Amar, M. I., Hazri, J., \& Najeemah, M. Y. (2013). Prejudis dan Stereotaip dalam Kalangan Murid Pelbagai Etnik di Sekolah Menengah Kebangsaan Malaysia. Proceeding of the Global Summit on Education (pp. 1011-1021). Malaysia: World Conferences.

Azhar, M. A. H., Rosman, M. Y., Fauzi, M. O., \& Koharuddin, M. B. (2013). Perspektif Orang Cina terhadap Agama Islam di Malaysia: Satu Tinjauan Awal. Jurnal Teknologi, 60, 11-19.

Ridhuan, M. T. A. (2010). Cabaran Integrasi Antara Kaum Di Malaysia: Perspektif Sejarah, Keluarga Dan Pendidikan. Jurnal Hadhari 3(61-84).

Noraini, M. N. (2007). Polarisation and inequality in Malaysia: The future of Malay-Chinese relations. Intellectual Discourse, 15 (2), 191 - 204.

Fong, F. (2018). Businessman's Unique Potato Approach to Helping the Poor. New Straits Times. https://www.nst.com.my/news/nation/2018/03/344471/businessmans-unique-potatoapproach-helping-poor

Operario, D., \& Fiske, S. (2003). Stereotypes: Content, Structures, Processes, and Context. In R. Brown \& S. Gaertner (Eds.), Blackwell handbook of social psychology: Intergroup processes. Malden, MA: Blackwell.

Pauker, K. B., Ambady, N., \& Apfelbaum, E.P. (2010). Race salience and essentialist thinking in racial stereotype development. Child Development, 81, 1799-1833.

Puddifoot, K. (2017). Stereotyping: The Multifactoraial View. Spring. 45 (1), 137-156. 
INTERNATIONAL JOURNAL OF ACADEMIC RESEARCH IN BUSINESS AND SOCIAL SCIENCES

Vol. 10, No. 16, Youth and Community Wellbeing: Issues, Challenges and Opportunities for Empowerment V2. 2020, E-ISSN: 2222-6990 @) 2020 HRMARS

Rabushka, A. (1971). Racial Stereotypes in Malaya. Asian Survey, 11 (7), 709 - 716.

Ramli, M., Zulkepli, M. I., Rahim, R. A., Razak, M. I., Hamdan, M. N., \& Marinsah, S. A. (2018). Isu-isu Sensitif dalam Masyarakat Majmuk di Malaysia Pasca Pilihanraya Umum (PRU-14): Aplikasi Pendekatan Kesederhanaan.

Rogers, W. S., \& Sands, W. (2011). Social Psychology (2 ${ }^{\text {nd }}$ Ed.). New York: McGraw Hill.

Saleh, N. H., \& Salleh, M. N. (2011) Pengambilan Minuman Beralkohol dalam Kalangan Pelajar dan Kaitannya dengan Pengaruh Rakan. In: 1st International Conference on World-Class Education 2011, 05-06 Dec 2011, University of Malaya.

Schneider, D. J. (2004). The Psychology of Stereotyping, Guilford Press, New York, NY

Schneider, D., Hastorf, A., \& Ellsworth, P. (1979). Person Perception (2nd ed.). Reading, Mass: AddisonWesley.

Shamsul, A. B. (2011). Kesepaduan dalam Kepelbagaian: Perpaduan di Malaysia sebagai Work-inprogress. Bangi: Penerbit Universiti Kebagsaan Malaysia.

Stangor, C. (2009). The study of stereotyping, prejudice, and discrimination within social psychology: A quick history of theory and research. In T. D. Nelson (Ed.), Handbook of prejudice, stereotyping, and discrimination (pp. 1-12). New York: Psychology Press.

Stangor, C., \& Schaller, M. (1996). Stereotypes as individual and collective representations. In C. Macrae, N., Stangor, C. \& Hewstone, M. (Eds.), Foundations of stereotypes and stereotyping (pp. 3-37). New York: Guilford.

Swettenham, F. (1967). Stories and Sketches by Sir Frank Swettenham. Kuala Lumpur: Oxford University Press.

Tajfel, H. (1982). Social psychology of intergroup relations. Annual Review of Psychology, 33, 1-39.

Tan, A., Dalisay, F., Zhang, Y., Han, E. J., \& Merchant, M. M. (2010). A cognitive processing model of information source use and stereotyping: African-American stereotypes in South Korea. Journal of Broadcasting \& Electronic Media, 54(4), 569-587.

Uhlmann, E. L., Poehlman, T. A., Tannenbaum, D., \& Bargh, J. A. (2011). Implicit Puritanism in American Moral Cognition. Journal of Experimental Social Psychology, 47 (2), 312 - 320.

Husin, W. N. (2012). Peradaban dan Perkauman di Malaysia: Hubungan Etnik Melayu-Cina / Wan Noorhasniah Wan Husin. Penerbit Universiti Malaya, Kuala Lumpur.

Yeoh, J. P. S., \& Yeoh, P. A. (2015). Competitiveness between Ethnic Malays and Ethnic Chinese in Malaysia. Journal of Psychology, 2 (1), 16 - 21.

Abidin, Z. A. W. (1997). Kesultanan Melayu Melaka: Pentadbiaran Kuno atau Moden? Institut Kajian Sejarah dan Patriotisme Malaysia (IKSEP), Malaysia. 